\title{
Pengaruh Pemberian Bahan Organik Kulit Biji Kopi Dan Zat Perangsang Tumbuh Hydrasil Pada Pertumbuhan Bibit Karet Okulasi Klon PB 260
}

\section{The Effect of Organic Skin Giving of Coffee Beans And Hydracid Growing Substance Growth In Rubber Seedling Growth Okulation Clone PB 260}

\author{
Wentricho Manullang, Retna Astuti K., dan Erwin Pane \\ Fakultas Pertanian, Universitas Medan Area, Indonesia \\ *Corresponding author: E-mail: wentrichoumafp@gmail.com
}

\begin{abstract}
Abstrak
Penelitian dilaksanakan di kebun percobaan Fakultas Pertanian Universitas Medan Area yang berlokasi di jalan Kolam No. 1 Medan Estate. Penelitian ini dilaksanakan pada bulan Mei 2013 sampai dengan Juli 2013. Penelitian ini bertujuan untuk mengetahui pengaruh pemberian bahan organik kulit biji kopi dan zat perangsang tumbuh terhadap pertumbuhan bibit karet okulasi. Rancangan yang digunakan yaitu Rancangan Acak Kelompok (RAK) Faktorial. Parameter yang diamati adalah panjang tunas, jumlah anak daun, luas daun, jumlah tangkai daun dan volume akar. Hasil penelitian menunjukkan bahwa semua parameter yang diamati tidak berbeda nyata pada perlakuan bahan organik kulit biji kopi (K) dengan empat taraf perlakuan $\mathrm{K} 0=$ kontrol (topsoil), $\mathrm{K} 1=1 \mathrm{~kg}+4 \mathrm{~kg}$ subsoil, $\mathrm{K} 2=2 \mathrm{~kg}+3 \mathrm{~kg}$ subsoil, $\mathrm{K} 3=3 \mathrm{~kg}$ $+2 \mathrm{~kg}$ subsoil dan zat perangsang tumbuh hydrasil $(\mathrm{H})$ dengan empat taraf $\mathrm{H} 0=$ Kontrol (1 liter air), $\mathrm{H} 1=1 \mathrm{ml} / 1$ liter air, H2= $2 \mathrm{ml} / 1$ liter air, H3= $3 \mathrm{ml} / 1$ liter air. Kesimpulan yang diperoleh dari penelitian ini adalah pemberian bahan organik kulit biji kopi dan zat perangsang tumbuh hydrasil tidak nyata meningkatkan pertumbuhan bibit karet okulasi. Namun demikian berdasarkan uji statistik beberapa parameter pengamatan seperti panjang tunas, jumlah anak daun dan jumlah tangkai daun mengalami rata-rata pertumbuhan meningkat pada umur 6 MST dan rataan pertumbuhan yang tidak stabil (inderterminate) pada umur 8 MST -12 MST.
\end{abstract}

Kata Kunci: Kulit Biji Kopi, ZPT Hydrasil, Bibit Karet, Klon PB 260

\begin{abstract}
The experiment was conducted in experimental field of Faculty of Agriculture, University of Medan Area, located at No. Pond Street. 1 Medan Estate. This research was conducted in May 2013 until July 2013. This study aims to determine the effect of giving the organic skin of coffee beans and stimulating substances to the growth of rubber grafting seeds. The design used is Randomized Block Design (RAK) Factorial. Parameters observed were shoot length, number of leaflets, leaf area, number of leaf stalk and root volume. The results showed that all observed parameters were not significantly different in the treatment of organic peanut skin ( $K$ ) with four treatment levels $K O=$ control (topsoil), $K 1=1 \mathrm{~kg}+4 \mathrm{~kg}$ subsoil, $K 2=2$ $\mathrm{kg}+3 \mathrm{~kg}$ subsoil, $\mathrm{K3}=3 \mathrm{~kg}+2 \mathrm{~kg}$ subsoil and hydraulic growth stimulant $(\mathrm{H})$ with four levels $\mathrm{HO}=$ Control (1 liter water), $H 1=1 \mathrm{ml} / 1$ liter water, $H 2=2 \mathrm{ml} / 1$ liter water, $H 3=3 \mathrm{ml} / 1$ liter of water. The conclusions obtained from this study is the provision of organic coffee bean skin and stimulants grows hydrasil not significantly increase the growth of rubber grafting seeds. However, based on statistical tests, some observation parameters such as shoot length, number of leaflets and number of leaf stalks experienced an average growth increase at age 6 MST and an unstable growth rate (inderterminate) at age 8 MST -12 MST.
\end{abstract}

Keywords: Coffee Bean Skin, ZPT Hydrasil, Rubber Seeds, Clone PB 260

How to Cite: Manullang W., Retna A. K. , Erwin P., (2016), Pengaruh Pemberian Bahan Organik Kulit Biji Kopi Dan Zat Perangsang Tumbuh Hydrasil Pada Pertumbuhan Bibit Karet Okulasi Klon PB 260, Jurnal Agrotekma, 1 (2): 111-125 


\section{PENDAHULUAN}

Karet merupakan salah satu komoditi pertanian yang penting di Indonesia, karena hasil devisa yang diperoleh dari karet cukup besar. Indonesia pernah menguasai produksi karet dunia hingga mencapai $80 \%$ pada tahun 2005 dengan menyisihkan negaranegara lain dan negara asal tanaman karet sendiri di daratan Amerika Selatan (Brazilia) (Anwar, 2008). Perkebunan karet Indonesia sebagian besar berada di wilayah Sumatera dan Kalimantan. Luas perkebunan karet Indonesia pada tahun 2005 adalah 4.363 .510 ha. Dari total area perkebunan karet di Indonesia tersebut $88,26 \%$ di antaranya merupakan perkebunan rakyat, $6,30 \%$ perkebunan swasta, dan hanya 5,45\% yang milik negara (Tim Penulis PS, 2008).

Permasalahan umum pada saat ini adalah asal usul bibit untuk perkebunan karet rakyat yang cukup luas tersebut tidak semuanya dari klon yang memiliki pruduktivitas tinggi. Pada tahun 2009, perkebunan karet milik negara dan perusahaan besar yang luasnya 538.300 ha mampu berproduksi 499.200 ton per tahun. Sedangkan perkebunan rakyat seluas 2.932 .600 ha hanya menghasilkan 2.123.600 ton per tahun. Jika dihitung produktivitasnya, perkebunan karet milik negara dan perusahaan besar mencapai 0,972 ton per ha, sedangkan perkebunan rakyat hanya 0,724 ton per ha (Parhusip, 2008). Hal ini sangat jauh dari potensi produksi untuk karet kering yang bisa dihasilkan tanaman karet saat ini yang mencapai 2,9 - 3,2 ton per ha per tahun (Balai Penelitian Sungei Putih, 2007).

Tanaman karet (Hevea brasiliensis Muell) adalah tanaman tahunan, satu siklus tanaman yang dihitung dari saat menanam di lapangan sampai dengan peremajaan mem akan waktu 25 tahun. Oleh karena itu pemilihan bahan tanam harus dipertimbangkan secara cermat karena adanya kekeliruan dalam pemilihan bahan tanam akan berdampak negatif terhadap perkebunan dan terhadap usaha karet alam nasional (Nazaruddin dan Paimin, 1992).

Bahan tanaman karet yang dianjurkan adalah bahan tanam klon yang diperbanyak secara okulasi. Dibandingkan dengan bibit semaian penggunaan bahan tanam klon sangat menguntungkan karena produktivitas tanaman lebih tinggi masa tanaman belum menghasilkan lebih cepat, tanaman lebih seragam sehingga produksi pada tahun sadap pertama lebih tinggi serta memiliki sifat sekunder yang diinginkan seperti relatif tahan terhadap penyakit tertentu, batang tegap, responsif terhadap stimulan dan pupuk, serta volume kayu per pohon tinggi. Dengan adanya perbaikan genetik tanaman untuk sifat-sifat tersebut di atas memungkinkan budidaya karet tidak hanya diharapkan lagi dari segi lateks tetapi kayu. Produksi biomassa pada saat ini bernilai ekonomi tinggi, karena kayu karet dapat mensubtitusi kayu ramin maupun kayu hutan lainnya (Azwar dan Suhendry dkk, 1998).

Berdasarkan Undang-undang No. 12 Tahun 1992 pasal 13 disebutkan bahwa klon/varietas yang dapat disebarluaskan harus berupa benih bina. Benih bina adalah varietas/klon yang sudah lepas dengan SK Menteri Pertanian. Berdasarkan hasil rumusan Lokakarya Nasional Pemuliaan Tanaman Karet tanggal 22-23 November 2005 yang 
diadakan oleh Pusat Penelitian Karet di Medan, klon-klon yang direkomendasi untuk periode 2006-2010 adalah sebagai berikut :

1. Klon Anjuran Komersial terdiri dari : 1) Klon penghasil lateks, yakni : BPM 24, BPM 107, BPM 109, IRR 104, PB 217, dan PB 260; 2) Klon penghasil lateks kayu, yakni : BPM 1, PB 330, PB 340, RRIC 100, AVROS 2037, IRR 5, IRR 32, IRR 39, IRR 42, IRR 112 dan IRR 118; 3) Klon penghasil kayu, yakni : IRR 70, IRR 71, IRR 72, IRR 78.

2. Klon Harapan terdiri dari : IRR 24, IRR 33, IRR 41, IRR 54, IRR 64, IRR 105, IRR 107, IRR 111, IRR 119, IRR 141, IRR 144, IRR 208, IRR 211, dan IRR 220.

Klon yang sudah lepas seperti GT 1, PR 255, PR 161, PR 300, PR 303, RRIM 600 ,RRIM 712, tetapi tidak masuk dalam rekomendasi masih dapat digunakan dengan beberapa pertimbangan, antara lain dengan memperhatikan kepentingan pengguna untuk penanaman klon tersebut pada wilayah tertentu (Pusat Penelitian Karet Sungai Putih, 2006).

Untuk mendapatkan hasil optimum dari tanaman karet, di samping faktorfaktor lingkungan dan jenis tanaman, maka cara kultur teknis juga menentukan tinggi rendahnya produksi, karena produksi merupakan interaksi dari ketiga faktor tersebut. Salah satu tindakan kultur teknis yang penting adalah waktu di pembibitan, yakni penggunaan stum dari klon unggul dengan pertumbuhan menentukan keberhasilan tanaman di lapangan. Bibit tanaman karet yang akan ditanam baik berasal dari biji maupun dari okulasi disebut dengan stum. Stum ada beberapa macam yaitu : 1). Stum pendek asal biji, panjang batangnya berkisar antara 40-50 cm, panjang akar 40-50 cm atau telah berumur 1-1,5 tahun, 2). Stum tinggi asal biji, panjang batang lebih dari 1,5 meter panjang akar berkisar $50-60 \mathrm{~cm}$ atau bibit tersebut telah berumur 1,5-2 tahun, 3). Stum mata tidur yang berasal dari okulasi dan dipotong setinggi 5 hingga $10 \mathrm{~cm}$ di atas mata okulasi, dengan panja ng akar 40-50 cm. mata entrisnya belum keluar atau masih dalam keadaan mentis pada saat bibit dipindahkan ke lahan (Sianturi, 2001).

Bahan organik mempunyai peranan penting dalam mempertahankan kesuburan fisik, kimia dan biologi tanah. Penambahan bahan organik membuat tanah bersifat lebih gembur, sehingga aerasinya lebih baik dan tidak mudah mengalami pemadatan dibandingkan dengan tanah yang mengandung bahan organik rendah. Bahan organik dalam tanah bermanfaat mempercepat aktivitas mikro organisme, sehingga meningkatkan kecepatan dekomposisi bahan organik dan mempercepat pelepasan hara (Sutanto, 2002). Pada umumnya limbah kulit kopi yaitu kulit kopi hanya dijadikan pakan ternak atau dibuang begitu saja tanpa dilakukan pengolahan misalnya pengomposan untuk dikembalikan ke tanah.

Limbah kulit kopi merupakan sumber bahan organik yang potensial untuk dikelola. Menurut Sudiarto dan Gusmaini (2004) luas areal perkebunan kopi dindonesia mencapai 1.158.369 ha dengan produksi 497.481 ton. Produksi kopi yang cukup besar akan berpotensi menghasilkan limbah kulit kopi yang cukup besar, dimana ratio antara biji kopi dengan limbah kulit kopi adalah 60: 40 . Pengolahan kopi secara basah akan 
menghasilkan limbah padat berupa kulit buah pada proses pengupasan buah (pulping) dan kulit tanduk pada saat penggerbusan (hulling). Limbah kulit kopi (pulpa) belum dimanfaatkan secara optimal, umumnya ditumpuk di sekitar lokasi pengolahan selama beberapa bulan, sehingga dapat menimbulkan bau busuk dan cairan yang mencemari lingkungan. Salah satu upaya untuk mengurangi dampak negatif terhadap lingkungan adalah pemanfaatan secara optimal limbah proses produksi kopi tersebut (Ditjen Perkebunan, 2006).

Penggunaan zat perangsang tumbuh banyak dilakukan pada tanaman hortikultur dan pangan, sedangkan pada tanaman perkebunan, khususnya digunakan pada pembibitan. Pemanfaatan limbah kulit kopi sebagai sumber bahan organik dan zat perangsang tumbuh hydrasil diuji coba pada bibit karet okulasi guna mengetahui pengaruh yang ditimbulkannya terhadap pertumbuhan bibit karet okulasi klon PB 260. Berdasarkan latar belakang di atas, maka penulis tertarik untuk melakukan penelitian dengan judul „Pengaruh Pemberian Bahan Organik Kulit Biji Kopi dan Zat Perangsang Tumbuh Hydrasil Terhadap Pertumbuhan Bibit Karet Okulasi Klon PB 260"

\section{METODE PENELITIAN}

Bahan-bahan yang digunakan dalam penelitian ini adalah bibit karet okulasi klon PB 260 yang berasal dari Pusat Penelitian Karet Sungai Putih, bahan organik kulit biji kopi yang diperoleh dari perkebunan kopi masyarakat yang berada di desa Hinalang Kabupaten Simalungun, zat perangsang tumbuh Hydrasil, topsoil, subsoil , air, dan bahan-bahan lainnya yang dibutuhkan.

Sedangkan alat-alat yang digunakan dalam penelitian ini adalah polibag ukuran $30 \mathrm{~cm} \times 40 \mathrm{~cm}$, tali plastik, cangkul, pisau, parang babat, meteran, gembor, handsprayer, skliper, penggaris, alat tulis, triplek, cat dan alat-alat lain yang diperlukan.

Penelitian ini menggunakan Rancangan Acak Kelompok (RAK) Faktorial yang terdiri dari 2 faktor yaitu Faktor perlakuan pengaruh dosis limbah kulit biji kopi (notasi $\mathrm{K}$ ) dengan empat taraf yaitu $\mathrm{K} 0=$ kontrol (topsoil), $\mathrm{K} 1=1 \mathrm{~kg}$ pupuk organik kulit kopi $+4 \mathrm{~kg}$ tanah subsoil per polibag, $\mathrm{K} 2=2 \mathrm{~kg}$ pupuk organik kulit kopi $+3 \mathrm{~kg}$ tanah subsoil per polibag, K3 = $3 \mathrm{~kg}$ pupuk organik kulit kopi $+2 \mathrm{~kg}$ tanah subsoil per polibag, Faktor perlakuanpemberian Zat Perangsang Tumbuh Hydrasil (notasi $\mathrm{H}$ ) dengan empat taraf yaitu: $\mathrm{HO}=$ kontrol (air), $\mathrm{H} 1=1$ $\mathrm{ml} / 1$ liter air $\mathrm{H} 2=2 \mathrm{ml} / \mathrm{l}$ liter air dan $\mathrm{H} 3$ $=3 \mathrm{ml} / \mathrm{l}$ liter air, Jumlah kombinasi perlakuan adalah $4 \times 4=16$ kombinasi.

Metode analisa yang digunakan Rancangan Acak Kelompok Faktorial (RAK) Faktorial ini sebagai berikut :

$$
Y i j k=\mu+p i+\beta j+\alpha k+\beta \alpha(j k)+\sum i j k
$$

Keterangan:

Yijk : Hasil pengamatan dari faktor $(\mathrm{K})$ taraf ke-j dan faktor $(\mathrm{H})$ taraf ke-k pada ulangan taraf ke-i

$\mu \quad$ : Efek nilai tengah

pi : Efek dari ulangan ke-i

$\beta j \quad$ : Efek dari perlakuan (K) pada taraf ke-j

$\alpha \mathrm{k} \quad$ : Efek dari perlakuan $(\mathrm{H})$ pada taraf ke-k 
$\beta \alpha(j k)$ : Efek interaksi antara faktor $\mathrm{K}$ pada taraf ke-j dan faktor H pada taraf ke$\mathrm{k}$

$\sum \mathrm{ijk} \quad$ : Efek galat dari perlakuan $\mathrm{K}$ pada ke-j dan perlakuan $\mathrm{H}$ pada taraf ke-k serta ulangan ke-i

Apabila analisis sidik ragam diperoleh hasil berbeda nyata dan sangat nyata, untuk mengetahui sejauh mana pengaruh sangat nyata dan perlakuan selanjutnya diuji beda rataan dengan uji jarak Duncan (Gomez, K. A dan Gomez, A. A, 1983).

Parameter yang diamati pada penelitian ini adalah panjang tunas $(\mathrm{cm})$, jumlah anak daun (helai), luas daun ( $\mathrm{cm} 2)$, jumlah tangkai daun (buah) dan volume akar (ml)

\section{Pelaksanaan Penelitian}

Areal yang akan digunakan sebagai tempat pembibitan dibersihkan dari segala jenis sampah, rumput-rumputan, batu, krikil, kemudian dibuat parit drainase di sekeliling areal dengan kedalaman $20 \mathrm{~cm}$ dari permukaan tanah. Media yang digunakan adalah tanah lapisan kedua (sub soil) dan permukaan tanah telah dibersihkan dari sisa-sisa akar, kayu, dan kotoran lainnya. Kemudian dimasukkan ke dalam polibag berukuran $25 \mathrm{~cm} \times 50 \mathrm{~cm}$ dan bagian atas polibag disisakan 1.5-2.0 cm tidak diisi tanah untuk tempat air penyiraman. Tanah yang telah diisi ke dalam polibag disusun sesuai dengan bagan penelitian pada areal yang telah dipersiapkan, dengan jarak antar polibag $30 \mathrm{~cm}$, jarak antar plot $50 \mathrm{~cm}$, dan jarak antar ulangan $100 \mathrm{~cm}$. Bibit yang digunakan adalah bibit okulasi tanaman karet klon PB 260 yang telah dipilih dan diseleksi. Bibit yang digunakan diperoleh dari Pusat Penelitian Karet Sungai Putih,
Kecamatan Galang Kabupaten Deli Serdang. Bibit karet okulasi klon PB 260 diseleksi berdasarkan kriteria batang bawah yang berasal dari klon AVROS 207 dan entres yang ditempel adalah mata ketiak dari klon PB 260. Bibit karet okulasi ditanam ke dalam polibag sesuai perlakuan. Sebelum ditanam terlebih dahulu dibuat lubang pada bagian tengah polibag menggunakan tugal. Selanjutnya bibit karet okulasi ditanam dengan mata okulasi menghadap Utara-Selatan, penanaman dilakukan secara padat untuk menghindari dari rongga-rongga udara.

Penyiraman dilakukan pada saat pagi hari dan sore hari, di pagi hari dilakukan penyiraman pada pukul 07.00 WIB sampai 09.00 WIB. Sedangkan pada sore hari dilakukan pada pukul 16.00 WIB sampai 18.00 WIB. Volume penyiraman untuk semua polibag sebanyak 0,5 liter/hari. Jika turun hujan maka tidak dilakukan penyiraman. Penyiangan gulma dalam polibag dilakukan secara manual, rotasi 2 minggu sekali atau tergantung pertumbuhan gulma. Sedangkan penyiangan gulma di luar polibeg dapat dilakukan secara manual ataupun kimiawi. Penunasan terhadap tunastunas liar pada batang bawah (bukan okulasi) dilakukan dengan rotasi 1 minggu sekali dengan menggunakan pisau tunas (Nurhayati, 2006). Pengendalian Organisme Pengganggu Tanaman (OPT) dilakukan pada saat bibit dipinda hkan ke polibag. Untuk menghindari serangan jamur digunakan fungisida yang bersifat sistemik dan kontak dengan bahan aktif Cabendazime 6,2\% + Mankozeb 73,8\% seperti Dalsene Mx 200 (Direktorat Perlindungan Perkebunan, 2006). 
Pemberian Bahan Organik Kulit Biji Kopi

Kriteria warna bahan organik kulit biji kopi yaitu berwarna coklat kehitaman tidak berbau ,remah, tidak larut dalam air, memiliki temperatur yang hampir sama dengan temperatur udara, tidak mengandung asam lemak yang menguap. Pemberian pupuk organik dilakuan dengan mencampurkannya dengan topsoil (K0) dan subsoil (K1, K2, dan K3) masing-masing dengan taraf perlakuan yang diujicobakan.

Selanjutnya Pemberian Zat

Perangsang Tumbuh Hydrasil. Zat perangsang tumbuh hydrasil diberikan dengan cara mencampurkan larutan bahan hydrasil dengan air sesuai dengan taraf perlakuan yang diujikan. Selanjutnya larutan yang sudah dicampur tersebut diaplikasikan dengan cara menyemprotkan larutan tersebut pada batang bibit okulasi PB 260 tanaman karet. Pemberian perlakuan zat perangsang tumbuh hydrasil disemprotkan satu kali, yakni setelah entres bibit karet okulasi klon PB 260 pecah atau tumbuh.

\section{HASIL DAN PEMBAHASAN}

Pengaruh Bahan Organik Kulit Biji Kopi Terhadap Pertumbuhan Bibit Karet Okulasi Klon PB 260.

Dari hasil penelitian dan uji statistik diperoleh hasil bahwa pengaruh pemberian bahan organik kulit biji kopi terhadap pertumbuhan bibit okulasi klon PB 260 tanaman karet (Hevea brasiliensis Muell) tidak berbeda nyata untuk semua parameter yaitu panjang tunas, jumlah anak daun, luas daun, jumlah tangkai daun, dan volume akar.
Panjang Tunas

Pada parameter panjang tunas bibit karet okulasi klon PB 260, pengaruh dosis bahan organik kulit biji kopi tidak berbeda nyata, hal ini dapat dilihat pada Tabel 1.

Tabel 1. Pengaruh Bahan Organik Kulit Biji Kopi Terhadap Panjang Tunas Bibit Karet Okulasi Klon PB 260

\begin{tabular}{|c|c|c|c|c|}
\hline 4 MST & $6 \mathrm{MST}$ & $8 \mathrm{MST}$ & $10 \mathrm{MST}$ & 12 MST \\
\hline $37.15 \mathrm{tn}$ & $68.57 \mathrm{tn}$ & 74.74 th & $83.48 \mathrm{tn}$ & $105.57 \mathrm{tr}$ \\
\hline $33.04 \mathrm{tn}$ & $64.48 \mathrm{tn}$ & $72.16 \mathrm{tn}$ & $78.98 \mathrm{tn}$ & $89.74 \mathrm{tn}$ \\
\hline $25.79 \mathrm{tn}$ & $58.90 \mathrm{tn}$ & $70.32 \mathrm{tn}$ & $79.41 \mathrm{tn}$ & 87.49 tn \\
\hline $35.88 \mathrm{tn}$ & $54.49 \mathrm{tn}$ & $65.23 \mathrm{tn}$ & $76.49 \mathrm{tn}$ & $87.15 \mathrm{tn}$ \\
\hline
\end{tabular}

Keterangan :

$$
\begin{aligned}
& \text { tn : tidak berbeda nyata } \\
& \text { MST : minggu setelah tanam }
\end{aligned}
$$

Rata-rata pertumbuhan panjang tunas tertinggi didapatkan pada bibit okulasi yang tanpa diberi perlakuan ( $\left.\mathrm{K}^{0}\right)$ sebesar $37.15 \mathrm{~cm}$ (4 MST) hingga 105.57 cm (12 MST). Sedangkan rata rata pertumbuhan panjang tunas terkecil terdapat pada perlakuan $\mathrm{K}^{2}$ sebesar 25.79 cm (4 MST) dan $\mathrm{K}^{3}$ sebesar $87.15 \mathrm{~cm}(12$ MST). Hal ini menunjukkan bahwa pertumbuhan panjang tunas tidak merata pada perlakuan selain $\mathrm{K}_{0}^{0}\left(\mathrm{~K}^{1}, \mathrm{~K}^{2}\right.$ dan $\left.\mathrm{K}^{3}\right)$ dalam setiap minggu pengamatan seperti yang terdapat pada Gambar 1.

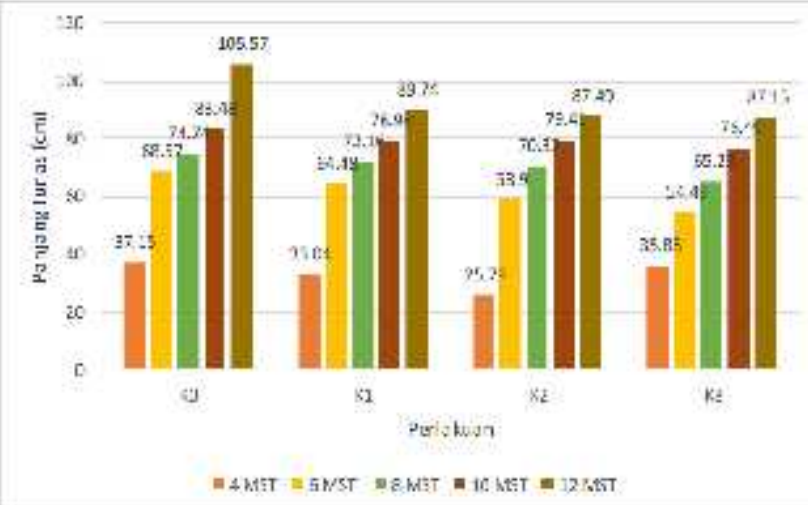

Gambar 1. Pemberian Bahan Organik Kulit Biji Kopi Terhadap Panjang Tunas $(\mathrm{cm})$ Bibit Karet Okulasi Klon PB 260 Pada Umur 4 MST Sampai Dengan 12 MST Pada Berbagai Taraf Perlakuan 
Berdasarkan Gambar 1 di atas pemberian bahan organik dapat meningkatkan pertumbuhan panjang tunas bibit karet okulasi klon PB 260 pada umur 6 MST walaupun pengaruh pemberian bahan organik kulit biji kopi berdasarkan data statistik tidak berbeda nyata.

\section{Jumlah Anak Daun}

Pada parameter jumlah anak daun bibit karet okulasi klon PB 260, pengaruh dosis bahan organik kulit biji kopi tidak berbeda nyata, hal ini dapat dilihat pada Tabel 2.

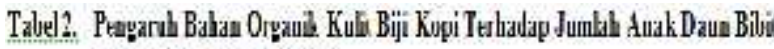 Karet Okinhas Kinn PB 550

\begin{tabular}{|c|c|c|c|c|c|}
\hline \multirow[b]{2}{*}{ Prlatinam } & \multicolumn{5}{|c|}{ 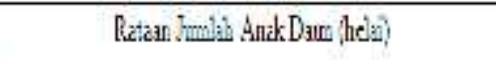 } \\
\hline & $4 \mathrm{MSL}$ & GXS: & SMS: & 1 MMI & [2.XS] \\
\hline $\mathrm{Ka}$ & 21.28 & 51.18 in & $58.19 t$ & $55.10 x$ & RS. in \\
\hline $\mathrm{k} 1$ & $15.81 \geq$ & 44.57 in & $2.15 \mathrm{~m}$ & $52.55=$ & 6807 in \\
\hline $\mathrm{K} 2$ & $113: 2$ & 11.32 in & $18.2 \mathrm{~m}$ & $532 x$ & $6290 \mathrm{tn}$ \\
\hline $\mathrm{K} 3$ & $780 m$ & $40.46 \mathrm{in}$ & $5499 \mathrm{~m}$ & 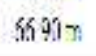 & $5274 \pi$ \\
\hline
\end{tabular}

Dari Tabel 2 di atas pemberian masing-masing perlakuan $\mathrm{K}_{0}, \mathrm{~K}_{1}, \mathrm{~K}_{2}$ dan $\mathrm{K}_{3}$ secara visual lebih meningkatkan penambahan jumlah anak daun bibit karet okulasi klon PB 260 tanaman karet di polibag pada umur 6 MST (minggu setelah tanam). Meski diberi unsur hara dalam jumlah yang sama pada saat pemupukan, namun kemampuan bibit dalam menyerap unsur hara dan mengalirkan hasil fotosintat akan berbeda antara tanaman yang satu dengan yang lain.

Luas Daun, Jumlah Tangkai Daun dan Volume Akar

Pada parameter luas daun, jumlah cabang dan volume akar bibit karet okulasi klon PB 260 pada umur 12 MST, pengaruh dosis bahan organik kulit biji kopi tidak berbeda nyata, hal ini dapat dilihat pada Tabel 3.

Tabel 3. Pengaruh Bahan Organik Kulit Biji Kopi Terhadap Luas Daun, Jumlah Tangkai Daun dan Volume Akar Bibit Karet Okulasi Klon PB 260 Pada Umur 12 MST

\begin{tabular}{|c|c|c|c|}
\hline Potlakuat: & 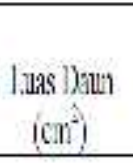 & $\begin{array}{c}\text { Rotaga } \\
\text { Itomlah langkai I)aut } \\
\text { lbuhhi }\end{array}$ & $\begin{array}{c}\text { Volleme dikat } \\
\text { imli }\end{array}$ \\
\hline $\mathrm{K}$ II & $7-50 \mathrm{bl}$ & $23 \mathrm{ML}$ & 19.4 \\
\hline $\mathrm{K}$. & 87.35 ta & $2320 \mathrm{LL}$ & 19.40ta \\
\hline$K_{2}$ & 13.86 & $20 \% \mathrm{~g}$ & $17,2 \mathrm{~h}$ \\
\hline $\mathrm{L}$ & 10.22 & $24.4 .2 . \mathrm{L}$ & 21.40 1 \\
\hline
\end{tabular}

Keterangan : tn : tidak berbeda nyata, MSI : minggu setelah tanam

Rata-rata pertambahan luas daun, jumlah tangkai daun dan volume akar tertinggi pada 12 MST terdapat K1 sebesar $87.29 \mathrm{~cm}^{2}$ (luas daun), K3 sebanyak 24.42 buah (jumlah tangkai daun) dan K3 sebesar $21.4 \mathrm{ml}$ (volume akar). Sedangkan hasil terkecil terdapat pada perlakuan $\mathrm{K}^{3}$ sebesar $70.22 \mathrm{~cm}^{2}$ (luas daun), K2 sebanyak 20.92 buah (jumlah tangkai daun) dan $\mathrm{K}^{2}$ sebesar $17.72 \mathrm{ml}$ (volume akar). Hal ini menunjukkan bahwa pertumbuhan dan perkembangan setiap parameter yang diamati tidak merata pada perlakuan pada 12 MST seperti yang terdapat pada Gambar 3.

Daun merupakan faktor pen-dukung pertumbuhan tanaman. Hal ini disebabkan karena daun sebagai organ utama untuk menyerap cahaya dan untuk melakukan fotosintesis pada tanaman. Daun yang luasnya besar akan membuat laju fotosintesis maksimal sedangkan daun yang luasnya kecil menyebabkan fotosintesis rendah, sehingga fotosintat yang dihasilkan relatif sedikit, terutama 
untuk mengembangkan luas daun sendiri. Ini menunjukkan bahwa unsur hara dan mineral dapat di angkut dan di gunakan dengan baik untuk proses fotosintesis dalam daun sehingga tanaman dapat tumbuh dengan baik ini terlihat pada tingginya luas daun pada bibit okulasi klon PB 260.

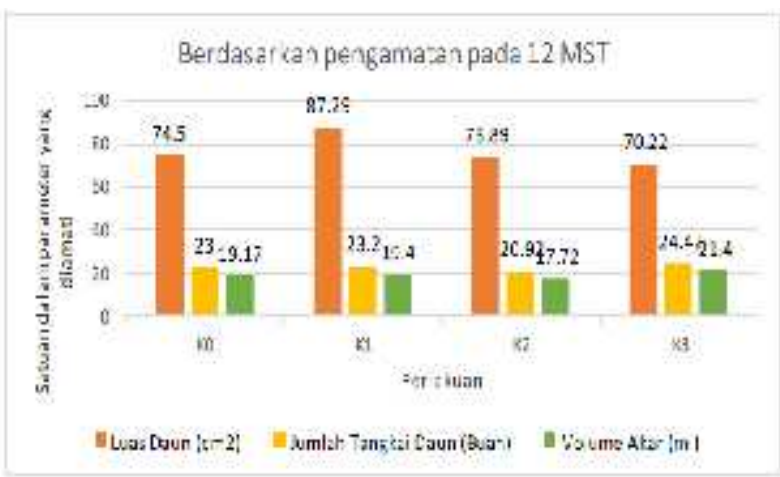

Gambar 3. Pemberian Bahan Organik Kulit Biji Kopi Terhadap Luas Daun (Cm2), Jumlah Tangkai Daun (Buah) Dan Volume Akar (Ml) Bibit Karet Okulasi Klon PB 260 Pada Berbagai Taraf Perlakuan

Laju dan kuantitas fotosintat dapat mempengaruhi pertumbuhan batang, selain itu kegiatan fotosintesis sangat dipengaruhi oleh faktor lingkungan seperti intensitas cahaya, suhu, air dan unsur hara (Lingga, 1995).

Pengaruh Zat Perangsang Tumbuh Hydrasil Terhadap Pertumbuhan Bibit Karet Okulasi Klon PB 260

Dari hasil penelitian dan uji statistik diperoleh hasil bahwa pengaruh pemberian zat perangsang tumbuh hydrasil terhadap pertumbuhan bibit karet okulasi klon PB 260 tidak berbeda nyata untuk semua parameter yaitu panjang tunas, jumlah anak daun, luas daun, jumlah tangkai daun, dan volume akar.

Panjang Tunas

Pada parameter panjang tunas bibit okulasi klon PB 260 tanaman karet (Hevea brasiliensis Muell), pengaruh zat perangsang tumbuh hydrasil tidak berbeda nyata, hal ini dapat dilihat pada Tabel 4.

Tabel 4. Pengaruh Zat Perangsang Tumbuh Hydrasil Terhadap Panjang Tunas Bibit Karet Okulasi Klon PB 260

\begin{tabular}{|c|c|c|c|c|c|}
\hline \multirow[b]{2}{*}{ Pothalen } & \multicolumn{5}{|c|}{ 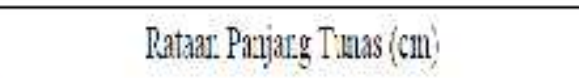 } \\
\hline & 4.MSI & 6 MST & 8NST & $10 \mathrm{MSI}$ & 12MST \\
\hline $\mathrm{Hil}$ & 3 is 10 & $49.22 \mathrm{~m}$ & $58 .<\mathrm{tan}$ & $6.56 \mathrm{th}$ & $86.5 \mathrm{tn}$ \\
\hline $\mathrm{Hl}$ & $31.40 \mathrm{ll}$ & $68.07 \mathrm{HI}$ & $n 51 \mathrm{~m}$ & 3982 u & $9765 \mid$ \\
\hline $\mathrm{H} 2$ & $39.98 \mathrm{~ms}$ & 69.20 & $76.9 \mathrm{mt}$ & $36.15 \pi$ & 9474 in \\
\hline $\mathrm{H}_{3}$ & 34.11 th & (610.57 & $67.19 \mathrm{t}$ & $82.19 \mathrm{tw}$ & Y.1. 11 t t \\
\hline
\end{tabular}

Keterangan : tn : tidak berbeda nyata, MST : minggu setelah tanam

Rata-rata pertumbuhan panjang tunas tertinggi didapatkan pada bibit karet okulasi yang diberikan perlakuan $\mathrm{H}^{2}(2$ $\mathrm{ml} / 1$ ilter air) sebesar $39.98 \mathrm{~cm}$ (4 MST) dan $\mathrm{H}^{1}(1 \mathrm{ml} / 1$ liter air $) 97.65 \mathrm{~cm}(12$ MST). Sedangkan pertumbuhan panjang tunas terkecil bibit karet okulasi didapatkan pada tanpa pemberian zat perangsang tumbuh hydrasil $(\mathrm{H} 0)$ sebesar $25.07 \mathrm{~cm}$ (4 MST) dan $86.15 \mathrm{~cm}$ (12 MST). Hal ini menunjukkan bahwa pertumbuhan panjang tunas tidak merata pada perlakuan $\mathrm{H}^{2}$ dan $\mathrm{H}^{1}$ setiap minggu pengamatan seperti yang terdapat pada Gambar 4.

Berdasarkan Gambar 4 di atas menunjukkan bahwa perlakuan zat perangsang tumbuh hydrasil meningkatkan pertumbuhan panjang tunas bibit karet okulasi klon PB 260 pada umur 6 MST hingga rata-rata pertumbuhan mencapai $\pm 50 \%$ dari pertumbuhan bibit pada 4 MST walaupun secara data statistik pemberian perlakuan tidak berbeda nyata. 


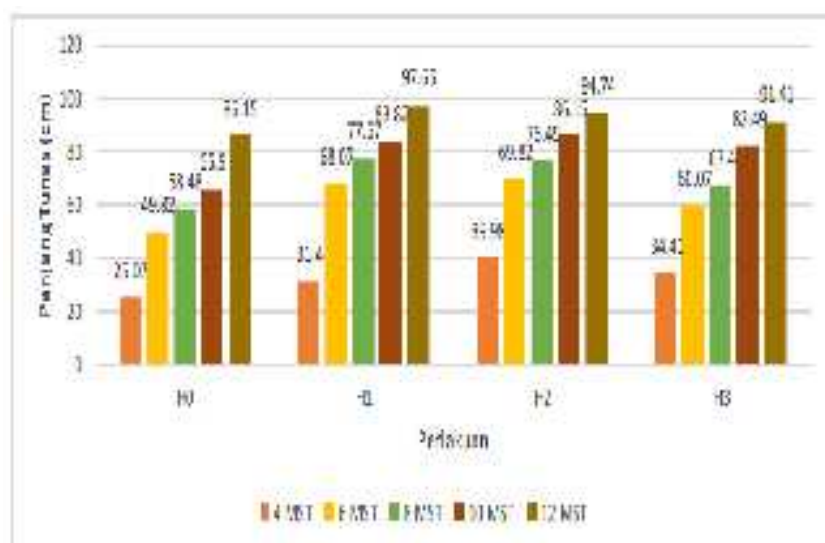

Gambar 4. Pemberian zat perangsang tumbuh hydrasil terhadap panjang tunas bibit karet okulasi klon PB 260 pada berbagai taraf perlakuan

Luas Daun, Jumlah Tangkai Daun dan Volume Akar

Pada parameter luas daun, jumlah tangkai daun dan volume akar bibit karet okulasi klon PB 260, pengaruh zat perangsang tumbuh hydrasil tidak berbeda nyata, hal ini dapat dilihat pada Tabel 5.

Tabel 5. Pengaruh Zat Perangsang Tumbuh Hydrasil Terhadap Luas Daun, Iumlah Tangkai Daun dan Volume Akar Rataan

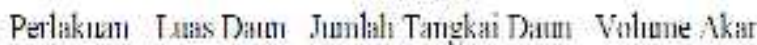
$\begin{array}{lll}\left(\mathrm{cm}^{3}\right) & (\text { buah) } & (\mathrm{ml})\end{array}$

\begin{tabular}{llll} 
ITO & $72.97 \mathrm{II}$ & $19.32 \mathrm{~m}$ & $17.72 \mathrm{~m}$ \\
II1 & $80.87 \mathrm{II}$ & $26.50 \mathrm{~m}$ & $20.22 \mathrm{~m}$ \\
$\mathrm{H} 2$ & $74.08 \mathrm{Im}$ & $21.07 \mathrm{~m}$ & $17.87 \mathrm{~m}$ \\
II & $77.99 \mathrm{~m}$ & $21.65 \mathrm{~m}$ & $22.17 \mathrm{~m}$ \\
\hline
\end{tabular}

Keterangan :

$\begin{array}{ll}\text { tn } & \text { : tidak berbeda nyata } \\ \text { MST } & \text { : minggu setela tanam }\end{array}$

Rata-rata pertambahan luas daun, jumlah tangkai daun dan volume akar tertinggi pada umur 12 MST terdapat $\mathrm{H}_{1}$ sebesar $80.87 \mathrm{~cm}^{2}$ (luas daun), $\mathrm{H}_{1}$ sebanyak 26.5 buah (jumlah tangkai daun) dan $\mathrm{H}_{3}$ sebesar $22.17 \mathrm{ml}$ (volume akar). Sedangkan hasil terkecil terdapat pada perlakuan $\mathrm{H}_{0}$ sebesar $72.97 \mathrm{~cm}^{2}$ (luas daun), $\mathrm{H}_{0}$ sebanyak 19.32 buah (jumlah tangkai daun) dan $\mathrm{H}_{0}$ sebesar $17.72 \mathrm{ml}$ (volume akar). Hal ini menunjukkan bahwa pertumbuhan dan perkembangan setiap parameter yang diamati tidak merata pada perlakuan pada umur 12 MST seperti yang terdapat pada Gambar 6.

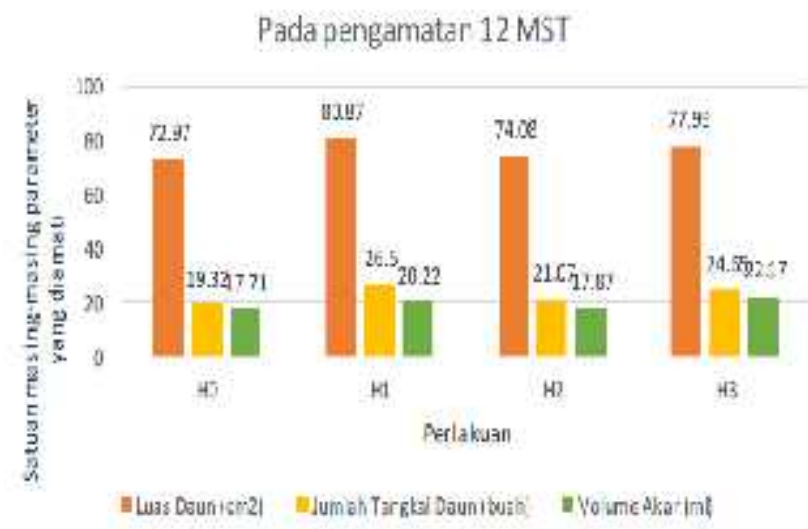

Gambar 6. Pemberian zat perangsang tumbuh hydrasil terhadap luas daun, jumlah tangkai daun dan volume akar bibit karet okulasi klon PB 260 pada berbagai taraf perlakuan.

Pengaruh Pemberian Bahan Organik Kulit Biji Kopi dan Zat Perangsang Tumbuh Hydrasil Terhadap Pertumbuhan Bibit Karet Okulasi klon PB 260

Dari hasil penelitian dan uji statistik diperoleh hasil bahwa pengaruh pemberian bahan kulit biji kopi dan zat perangsang tumbuh hydrasil terhadap pertumbuhan bibit karet okulasi klon PB 260 tidak berbeda nyata untuk semua parameter yaitu panjang tunas, jumlah anak daun, luas daun, jumlah tangkai daun, dan volume akar.

\section{Panjang Tunas}

Pada parameter panjang tunas bibit karet okulasi klon PB 260, pengaruh pemberian bahan organik kulit biji kopi dan zat perangsang tumbuh hydrasil tidak berbeda nyata. 
Berdasarkaan rataan panjang tunas diperoleh hasil tertinggi panjang tunas pada umur 4 MST akibat pengaruh perlakuan $\mathrm{K}_{1} \mathrm{H}_{2}$ sebesar $16.55 \mathrm{~cm}$ sedangkan terkecil terdapat pada perlakuan $\mathrm{K}_{2} \mathrm{H}_{0}$ sebesar $6.33 \mathrm{~cm}$. Pada pengamatan 12 MST hasil tertinggi diperoleh dari perlakuan $\mathrm{K}_{0} \mathrm{H}_{0}$ sebesar $41.22 \mathrm{~cm}$ dan terkecil terdapat pada perlakuan $\mathrm{K}_{3} \mathrm{H}_{3}$ sebesar $23.55 \mathrm{~cm}$. Hal ini diduga karena interaksi antara pemberian pupuk organik dan zat perangsang tumbuh hydrasil tidak dapat saling merespon dengan baik.

Tabel 6. Pengaruh Pemberian Bahan Organik Kulit Biji Kopi dan Zat Perangsang Tumbuh Hydrasil Terhadap Panjang Tunas Bibit Karet Okulasi Klon PB260

Ratasn Parjayg Tuas icul

\begin{tabular}{|c|c|c|c|c|c|}
\hline Perlitinan & $4 \mathrm{MST}$ & 6KST & $8 \mathrm{NSI}$ & IOMST & $12 \mathrm{KST}$ \\
\hline Kallo & $01.33 \mathrm{x}$ & $18.55 \mathrm{tl}$ & $20.11 \mathrm{ta}$ & 22.11 to & $41.22 \mathrm{ta}$ \\
\hline $\mathrm{KOHI}$ & $222 x$ & $3022 \mathrm{b11}$ & 32.58 口 & 35550 & 30.77 to \\
\hline KOLI2 & $680 \pi$ & $26.11 \mathrm{~m}$ & $2 ., 11$ t t I & 31.63 ta & 34.21 ta \\
\hline $\mathrm{KOH} 3$ & $510 \mathrm{n}$ & $162 \mathrm{~m}$ & $17.88 \mathrm{n}$ & $21.66 \mathrm{ll}$ & 2555111 \\
\hline $\mathrm{KLHO}$ & $7.18 \quad x$ & $17.37 \mathrm{at}$ & $20.22 \mathrm{~m}$ & $21.66 \mathrm{t}$ & 2399 tמ \\
\hline $\mathrm{k} \| \mathrm{II}$ & 7.3311 & $19.55 \mathrm{~m}$ & $2 ? .55 \mathrm{tn}$ & $24.44 \mathrm{tn}$ & $29.21 \mathrm{th}$ \\
\hline $\mathrm{KLH} 2$ & 622.0 & 20.1iㅣ & 20.63 l ll & 23.77 1 & 28.33 i l \\
\hline $\mathrm{KlH} 3$ & $3.33 \mathrm{~T}$ & $2 x, 8 \leqslant$ u & $32.11 \mathrm{t}$ th & 35.11 ta & 38.11 ta \\
\hline KथाTी & $6.33 \mathrm{n}$ & 1266 & $10,44 \mathrm{l} 11$ & 21.79 & $2: 21$ i \\
\hline $\mathrm{K} 2 \mathrm{HI}$ & $115 \pi$ & $22.11 \mathrm{dI}$ & $24.44 \mathrm{mil}$ & $26.66 \mathrm{t}$ & 31.55 th \\
\hline K.2112 & $8.77 x$ & 20,22 แ & $22.53 \mathrm{t}$ & 25.33 to & 2x.2.ta \\
\hline $\mathrm{K} 2 \mathrm{H} 3$ & $8.11 \mathrm{n}$ & $23: 55 \mathrm{mI}$ & $27: 34$ ו ו1 & $32.1 \%$ L & 846641 \\
\hline K3III & $9.32 \mathrm{n}$ & $1477 \mathrm{II}$ & $17 . \mathrm{sR}^{2} \mathrm{H}$ & 20,4913 & $24.4+13$ \\
\hline $\mathrm{K} 3 \mathrm{HI}$ & $.185 \mathrm{D}$ & $18.36 \mathrm{ln}$ & $22.55 \mathrm{lll}$ & 25.10 10 & $2565 \mathrm{la}$ \\
\hline K3112 & عآ & $26.99 \mathrm{tal}$ & $30, .80$ t & $3: 13$ ta & 38.55 ta \\
\hline $\mathrm{K} 3 \mathrm{H}_{3}$ & $952 \mathrm{x}$ & 11.99611 & $15.66 \mathrm{~m}$ & 2077 t & 225510 \\
\hline
\end{tabular}

Keterangan :

tn : tidak berbeda nyata

MST : minggu setelah tanam

Selain hal tersebut kondisi bahan organik yang belum terdekomposisi dengan maksimal juga diperkirakan tidak dapat memberikan sumber hara yang dibutuhkan bibit karet okulasi klon PB 260 dalam media dengan maksimal pula. Terbukti pertumbuhan yang tidak merata pada panjang tunas bibit karet okulasi klon PB 260 pada minggu ke-8 sampai minggu ke-12, melain rata-rata pertumbuhan panjang tunas hanya meningkat sejak umur 6 MST seperti yang terdapat pada Gambar 7.

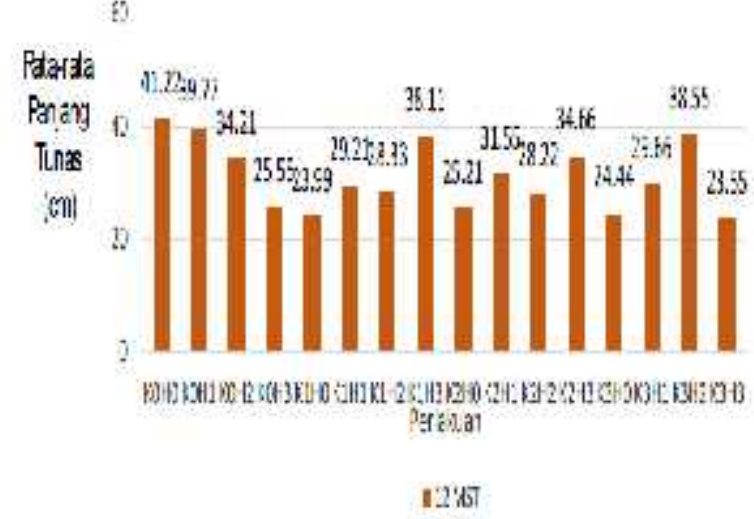

Gambar 7. Pemberian Bahan Organic Kulit Biji Kopi Dan Zat Perangsang Tumbuh Hydrasil Terhadap Panjang Tunas Bibit Karet Okulasi Klon PB 260 Pada Umur 12 MST

Jumlah Anak Daun

Pada parameter jumlah anak daun bibit karet okulasi klon PB 260, pengaruh pemberian bahan organik kulit biji kopi dan zat perangsang tumbuh hydrasil tidak berbeda nyata. Berdasarkaan rataan jumlah anak daun yang terdapat pada tabel 8 hasil tertinggi jumlah daun pada umur 4 MST akibat pengaruh perlakuan $\mathrm{K}_{3} \mathrm{H}_{3}$ sebesar 8.66 helai sedangkan terkecil terdapat pada perlakuan $\mathrm{K}_{2} \mathrm{H}_{0}$ sebesar 1.66 helai. Pada pengamatan 12 MST hasil tertinggi diperoleh dari perlakuan $\mathrm{K}_{0} \mathrm{H}_{1}$ sebesar 31.66 helai dan terkecil terdapat pada perlakuan $\mathrm{K}_{3} \mathrm{H}_{3}$ sebesar 16.88 helai.

Perbedaan rataan hasil jumlah anak daun selama percobaan diduga per- 
tumbuhan dan perkembangan bibit tanaman yang lambat akibat hara yang terdapat dalam polibag terbawa air pada saat penyiraman dilakukan. Selain hal tersebut perpaduan batang bawah dengan mata tunas bahan tanam juga mempengaruhi kemampuan bibit okulasi dalam menyerap hara.

Tabel 7. Pengaruh Pemberian Bahan Organik Kulit Biji Kopi dan Zat Perangsang Tumbuh Hydrasil Terhadap Jumlah Anak Daun Bibit Karet Okulasi Klon PB 260

\begin{tabular}{|c|c|c|c|c|c|}
\hline \multirow[b]{2}{*}{ Pethitizan } & \multicolumn{5}{|c|}{ 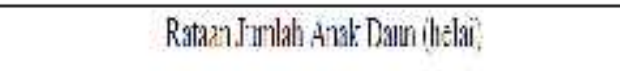 } \\
\hline & 4YS1 & $6 . \mathrm{HS}$ & BSSI & IIMSI & 12 is] \\
\hline KIII & $\therefore 66 \pi$ & $16.22 \mathrm{~m}$ & $18.11 \mathrm{ta}$ & 20ínín & $2841 \mathrm{tn}$ \\
\hline KIII] & $755 \mathrm{ll}$ & 2.91 & 655 al & $287 \mathrm{ul}$ & $3166 \mathrm{t}$ \\
\hline KOII2 & 1.827 & $11.22 \mathrm{~m}$ & $163 i \pi$ & $19.21 \mathrm{~m}$ & 21 利 th \\
\hline KIIB & $14,33.11$ & 1:.2211 & 1656 a & 15,8511 & 2266 t \\
\hline $\mathrm{KJHO}$ & $3.15 \mathrm{II}$ & 12.1. $\mathrm{m}$ & 14.38 all & $17.8 \mathrm{~m}$ & 183210 \\
\hline KJHI & 5.10 . II & $14.10 \mathrm{lal}$ & 15:88 all & 1). 4 th & $2253 \mathrm{l}$ \\
\hline $\mathrm{KlH} 2$ & $7.85 \mathrm{Il}$ & $155 \mathrm{~m}$ & 171 ta & $1933 \mathrm{~m}$ & 2055 to \\
\hline KITS & fit II & $1766 \mathrm{~m}$ & $20.3 i \pi$ & $26.8 \mathrm{~m}$ & 393 in \\
\hline $\mathrm{K}: \mathrm{HO}$ & 24. II & 1022 ta & 12.11 & $14.3 \hat{y}$ tn & 1638 to \\
\hline K:T1 & $796 \mathrm{II}$ & $14.33 \mathrm{~m}$ & 16411 & $20.2 \mathrm{~m}$ & $20399 \mathrm{tr}$ \\
\hline K.:L2 & 5000.11 & 1:221 & 18.99 d & $15,33 \mathrm{lll}$ & $2100 \mid$ \\
\hline KET3 & 3.110 & $1.313 \mathrm{~m}$ & $18.88 \mathrm{it}$ & $22: 5 \mathrm{~m}$ & $2199 \mathrm{in}$ \\
\hline $\mathrm{K}: \mathrm{HO}$ & $60^{7}=\mathrm{ll}$ & $11.55 \mathrm{ta}$ & 14.21 tu & 1750 th & 1) 44 to \\
\hline K:HI & $818 \mathrm{II}$ & $15.33 \mathrm{~m}$ & 2155 al & 2:11 th & 355 to \\
\hline $\mathrm{K}: \mathrm{H}^{2}$ & $8.33 \mathrm{NI}$ & 13.H til & $23.66 \mathrm{bil}$ & 26.33 tal & $27.91 \mathrm{t}$ \\
\hline $\mathrm{K}: 13$ & IA. II & 13,63 Lil & 16,70 ill & 21.77 ul & $3+1010$ \\
\hline
\end{tabular}

Keterangan :

th : tidak berbeda nyata

MST : minggu setelah tanam

Berdasarkan diagram pengaruh pemberian bahan organik kulit kopi dan zat perangsang tumbuh hydrasil terhadap jumlah anak daun yang terdapat pada Gambar 8 disimpulkan bahwa peningkatan pertumbuhan bibit karet okulasi klon PB 260 lebih tinggi sejak 6 MST.

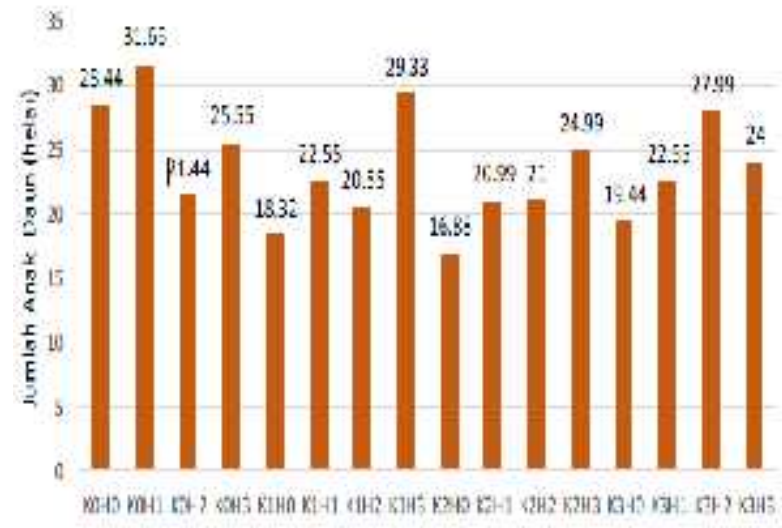

Gambar 8. Pemberian Bahan Organik Kulit Biji Kopi Dan Zat Perangsang Tumbuh Hydrasil Terhadap Jumlah Anak Daun Bibit Karet Okulasi Klon PB 260 Pada Umur 12 MST

Luas Daun Jumlah Tangkai Daun dan Volume Akar

Pada parameter luas daun, jumlah tangkai daun dan volume akar bibit karet okulasi klon PB 260, pengaruh pemberian bahan organik kulit biji kopi dan zat perangsang tumbuh hydrasil tidak berbeda nyata. Berdasarkan tabel rataan luas daun, jumlah tangkai daun dan volume akar yang terdapat pada Tabel 9 diperoleh hasil pengamatan tertinggi pada umur 12MST terdapat pada perlakuan $\mathrm{K} 1 \mathrm{H} 2$ sebesar $33 \mathrm{~cm} 2$ (luas daun), K0H1 sebesar 10.43 buah (jumlah tangkai daun) dan K1H3 sebesar $8.86 \mathrm{ml}$ (volume akar). Sedangkan hasil terkecil terdapat pada perlakuan K0H0 sebesar $19.55 \mathrm{~cm} 2$ (luas daun), K2H0 sebesar 6.2 buah (jumlah tangkai daun) dan $\mathrm{K} 2 \mathrm{H} 1$ sebesar $4.96 \mathrm{ml}$ (volume akar). Pertumbuhan bibit karet okulasi klon PB 260 pada parameter luas daun, jumlah tangkai daun dan volume akar akibat interaksi pemberian bahan organik kulit biji kopi dan zat perangsang tumbuh hydrasil seperti yang terdapat pada Gambar 9 tidak merata. Pemberian kedua jenis perlakuan melalui taraf perlakuan yang diujicobakan pada 
bibit tidak menjadi jaminan untuk untuk semua parameter. Hal ini pertumbuhan dan perkembangan bibit yang baik. Perpaduan antara batang bawah dengan mata tunas yang diokulasi di duga menjadi penyebab tidak seragamnya pertumbuhan bibit pada polibag karena kemampuan bibit dalam menyerap hara dalam polibag juga berbeda.

Tabel 9. Pengaruh Pemberian Bahan Organik Kulit Biji Kopi Dan Zat Perangsang Tumbuh Hydrasil Terhadap Luas Daun, Jumlah Tangkai Daun Dan Volume Akar Bibit Karet Okulasi Klon PB 260 Pada Umur

\begin{tabular}{|c|c|c|c|}
\hline Perlakıan & $\begin{array}{c}\text { I.Itas 1)guri } \\
\left(\mathrm{cm}^{2}\right)\end{array}$ & $\begin{array}{c}\text { Ralaun } \\
\text { Juthlah langhai I)mai } \\
\text { (buali) }\end{array}$ & $\begin{array}{l}\text { Volmule Aknt } \\
\text { (ml) }\end{array}$ \\
\hline $\mathrm{KOHII}$ & $19.55 \mathrm{III}$ & 5.96 in & $5.63 \mathrm{ln}$ \\
\hline $\mathrm{KOH} 1$ & $30.53 \mathrm{ll}$ & $10.1,3 \mathrm{II}$ & $7.13 \mathrm{11}$ \\
\hline KOII2 & $23.60 \mathrm{th}$ & $6.20 \mathrm{tu}$ & $6.26 \mathrm{th}$ \\
\hline $\mathrm{KOH} 3$ & $25.64 \mathrm{III}$ & $8.06 \mathrm{IIII}$ & 6.6 .711 \\
\hline K.HO & $27.21 \mathrm{kn}$ & $6.40 \mathrm{~W}$ & $5.20 \mathrm{im}$ \\
\hline KIII! & 25.13 th & $8.06 \mathrm{tu}$ & 6.60 th \\
\hline KIII2 & $33.00 \mathrm{te}$ & $7.30 \mathrm{cu}$ & 8.86 th \\
\hline KIII. & $31.00 \mathrm{th}$ & 9.16 th & 5.50 th \\
\hline $\mathrm{K} 2110$ & $27.61 \mathrm{ln}$ & $6.20 \mathrm{H}$ & $4.96 \mathrm{is}$ \\
\hline K2II! & 24.49 th & $7.06 \mathrm{tu}$ & 5.73 th \\
\hline K2II 2 & $20.07 \mathrm{th}$ & $7.20 \mathrm{~m}$ & 7.43 th \\
\hline $\mathrm{K} 2 \mathrm{H}_{3}$ & $26.31 \mathrm{III}$ & $7.15 \mathrm{III}$ & $7.30 \mathrm{~m}$ \\
\hline K3110 & $22.88 \mathrm{th}$ & $.20 \mathrm{tw}$ & $: y 6$ th \\
\hline K3III & 27.67 th & 9.76 th & 7.96 th \\
\hline K3II & $22.08 \mathrm{tu}$ & 7.40 ש & 6.63 th \\
\hline $\mathrm{K} .3 \mathrm{H} 3$ & $21.601 \mathrm{II}$ & $\times .20 \mathrm{III}$ & $6.63 \mathrm{ln}$ \\
\hline
\end{tabular}

\section{PEMBAHASAN}

Pengaruh Bahan Organik Kulit Biji Kopi Terhadap Pertumbuhan Bibit Karet Okulasi Klon PB 260

Pemberian bahan organik kulit biji kopi tidak mendorong pertumbuhan bibit karet okulasi klon PB 260. Taraf perlakuan pada penelitian yang diberikan yang terdiri dari K1, K2, K3 masing-masing sebesar $1 \mathrm{~kg}, 2 \mathrm{~kg}$ dan $3 \mathrm{~kg}$ tidak memberikan pengaruh tidak berbeda nyata terhadap semua parameter dalam pengamatan. Berdasarkan data pengamatan pada percobaan perlakuan pada K0 (tanpa bahan organik) lebih tinggi

disebabkan karena kondisi bahan organik limbah kopi belum terdekomposisi secara maksimal sehingga proses perpaduan dengan tambahan tanah subsoil yang kandungan haranya rendah pada media polibag lambat terurai dan diserap oleh akar bibit karet okulasi klon PB 260 sehingga perlakuan tanpa bahan organik dengan menggunakan tanah topsoil yang kandungan haranya lebih tinggi daripada tanah subsoil lebih cepat diserap oleh bibit karet okulasi klon PB 260 dan pertumbuhan lebih cepat.

Pertumbuhan tanaman di lapangan selain dipengaruhi oleh genetik, juga dipengaruhi oleh keadaan unsur hara yang ada di lahan. Dengan ketersediaan unsur hara yang mencukupi maka pertumbuhannya akan optimal. Menurut Syarif (1999), ketersediaan unsur hara yang cukup selama pertumbuhan akan meningkatkan proses fotosintesis, sehingga pembelahan, pembesaran dan diferensiasi sel akan lebih baik. Dalam pertumbuhan bibit karet okulasi di polibag, aliran suplai hara dari tanah menuju ke daun dan suplai fotosintat dari daun ke bagian lain sangat dipengaruhi oleh kesesuaian antara entres dan batang bawah. Aliran unsur hara dan hasil fotosintat harus melewati bagian okulasi untuk sampai pada tujuannya (akar dan daun). Jika bagian okulasi tidak tumbuh dengan baik maka secara otomatis tanaman tersebut akan terganggu pertumbuhannya. Sedangkan jika okulasi tersebut sesuai maka suplai hara dan hasil fotosintat akan dapat disalurkan dengan lancar sehingga pertumbuhan tanaman akan optimal (Lingga, 1994). 
Masalah yang dihadapi dalam pengembangan tanaman karet pada tanah ini adalah $\mathrm{pH}$ dan kandungan bahan organik rendah, miskin hara kalium $(\mathrm{K})$, kalsium (Ca) dan magnesium (Mg) serta mempunyai daya fiksasi $\mathrm{P}$ tinggi kahat unsur hara mikro. Selain pemupukan unsur hara makro seperti $\mathrm{N}, \mathrm{P}$, dan $\mathrm{K}$ untuk mengatasi kendala tersebut pemupukan hara mikro seperti $\mathrm{Mn}, \mathrm{Cu}, \mathrm{Zn}$ dan B akan menentukan keberhasilan pengembangan tanaman karet selanjutnya pada tanah ini. Sehingga untuk mengatasi kendala kesuburan tanah pada tanah ini maka pemeliharaan agar bibit karet pertumbuhannya sehat memegang peranan penting dalam meningkatkan pertumbuhandan produktivitas tanaman dikemudian hari. Faktor kesehatan tanaman pada fase pembibitan sangat ditentukan oleh tingkat pemeliharaan bibit setelah fase okulasi sampai siap dindahkan ke lapang diantaranya melalui pemupukan yang tepat sesuai dengan kebutuhan tanaman (Chairil Anwar, 2001).

Pengaruh Zat Perangsang Tumbuh Hydrasil Terhadap Pertumbuhan Bibit Karet Okulasi Klon PB 260

Pemberian zat perangsang tumbuh hydrasil dengan dosis perlakuan tidak memberikan pengaruh pertumbuhan yang baik pada bibit okulasi klon PB 260 tanaman karet (Hevea brasiliensis Muell) di polibag walaupun secara visual beberapa bibit okulasi yang tumbuh mengalami pertumbuhan yang berbeda dengan yang lainnya seperti pada perlakuan H3 pada ulangan 2 dalam percobaan. Hal ini diduga pada tunas bibit okulasi tanaman karet yang belum tumbuh itu dikarenakan kadar giberelin atau yang lebih dikenal asam giblet yang terdapat di dalam tanaman rendah, sehingga dormansi tunas dapat dihindari dengan pemberian giberelin eksogen yang terdapat pada zat perangsang tumbuh. Satu cara untuk menghilangkan proses dormansi pada mata tunas yaitu dengan pemberian giberelin Wattimena, (1987). Bibit okulasi yang berasal dari entres yang berbeda memiliki kemampuan menyerap dan menyalurkan unsur hara yang berbeda, sehingga pertumbuhannya pun menjadi berbeda (Lingga, 1995).

Pengaruh Bahan Organik Kulit Biji Kopi dan Zat Perangsang Tumbuh Hydrasil Terhadap Pertumbuhan Bibit Karet Okulasi Klon PB 260

Pemberian bahan organik kulit biji kopi memberi pengaruh yang tidak berbeda nyata dengan pemberian zat pengatur tumbuh hydrasil. Bahan organik kulit biji kopi dan zat perangsang tumbuh hydrasil tidak meningkatkan pertumbuhan bibit karet okulasi klon PB 260 untuk semua parameter yang diamati.

Sebagaimana tanaman lainnya, tanaman karet memerlukan hara makro dan mikro untuk proses metabolisme dalam jaringan. Pertumbuhan tanaman yang diperbanyak melalui okulasi, setelah bahan tanam ditanam, substrat yang terdapat di dalam batang seperti karbohidrat, lemak, dan protein akan mengalami perombakan secara enzimatik untuk mendukung aktivitas embrio atau tunas pembentuk bakal tanaman. Kemudian membentuk organ-organ utama tanaman lainnya seperti batang, akar dan daun. Pertumbuhan awal organ-organ ini sangat tergantung pada cadangan 
makanan (karbohidrat dan unsur-unsur lainnya) serta efisiensi metabolisme. Setelah substrat awal habis digunakan, penyediaan substrat selanjutnya tergantung pada luas daun dan efisiensinya memfiksasi CO2 (Sitompul, 1995).

Persentase pertumbuhan dan perkembangan bibit okulasi sangat lambat, hal ini terlihat sejak pengamatan 6 MST hingga 12 MST seperti yang terdapat pada Lampiran 6-41. Kematian bibit okulasi tanaman karet dalam percobaan juga merupakan hal yang sangat rentan terjadi diakibatkan beberapa bibit okulasi yang terserang oleh organisme pengganggu tanaman (OPT). Seperti yang terdapat pada Warta Penelitian dan Pengembangan Tanaman Industri (2012) Kelebihan dari bibit okulasi tanaman karet adalah ringan sehingga mudah diangkut dan biayanya murah, sedangkan kelemahannya adalah persentase kematian bibit lebih besar. Hal ini disebabkan bibit okulasi tanaman karet pada polibeg terserang penyakit jamur akar putih (Rigidoporus, sp), antraknose (Colletotrichum gloeosporioides), dan embun tepung (Oidium heveae).

Dari pengamatan yang dilakukan persentase kematian bibit karet okulasi klon PB 260 hingga pada pengamatan terakhir (12 MST) mencapai 136 batang (47.22\%) diduga disebabkan serangan penyakit dan kesalahan teknis seperti okulasi dan kesalahan lainnya (human error) selama penelitian.

\section{SIMPULAN}

1. Pemberian bahan organik kulit biji kopi tidak nyata meningkatkan partumbuhan bibit karet okulasi klon PB 260.
2. Pemberian zat perangsang tumbuh hydrasil tidak nyata meningkatkan pertumbuhan bibit karet okulasi klon PB 260.

3. Pemberian bahan organik kulit biji kopi dan zat perangsang tumbuh hydrasil tidak meningkatkan pertumbuhan bibit karet okulasi klon PB 260. Namun demikian berdasarkan uji statistik beberapa parameter pengamatan seperti panjang tunas, jumlah anak daun dan jumlah tangkai daun mengalami rata-rata pertumbuhan meningkat pada umur 6 MST dan ratarata pertumbuhan yang tidak stabil (inderterminate) pada umur 8 MST sampai umur 12 MST.

\section{DAFTAR PUSTAKA}

Anwar, C. 2006. Manajemen Dan Teknologi Budidaya Karet. Pusat Penelitian Karet Sei Putih. http:// www.ipard.com/ art_ perkebun/ MANAJEMEN $\% 20 \quad$ DAN\%2O

TEKNOLOGI\%20 BUDIDAYA\%20 KARET. pdf [06 Juni 2010].

Azwar, R. dan Suhendry. 1992. Pemanfaatan Klon Karet Unggul Dalam Penanaman Komersial Perusahaan Perkebunan. Prospek Lokakarya Nasional Pemuliaan Tanaman Karet.

BPLPP. Balai Pendidikan, Latihan dan Penyuluhan Pertanian. 2008. Karet, United National

Development Program Food and Agriculture Organization of United National. Bogor

Balai Penelitian Sungai Putih. 2007. Klon Karet Anjuran 2006 - 2010. Medan. 66 hal.

Basuki dan Tjasadihardja 1995. Masalah kerusakan karena angin pada tanaman karet dan upaya penanggulangannya. Forum Komunikasi Perkebunan VI, PTP IV Gunung Pamela, Pusat Penelitian Perkebunan Sungei Putih, Medan

Direktorat Perlindungan Perkebunan, Ditjen Perkebunan 2006. Pedoman Pemanfaatan Limbah dari Pembukaan Lahan.

Direktorat Jenderal Perkebunan. 2008. Perkembangan Kopi Dunia dan Pengaruhnya Bagi Indonesia dalam http:// 
pse. litbang. deptan. go. id/ ind/pdffiles. Diakses pada 23 November 2010

Gardner,P.F, Pearce,R.B dan Mitchell. 1991. Fisiologi Tanaman Budidaya. Penterjemah

Herawati Susilo. Universitas Indonesia Press. Jakarta

Kuswanhadi. 1991. Pengaruh Zat Pengatur Tumbuh dan Pupuk Daun Pada Tanaman Karet di Polibag. Pusat Penelitian Karet Sembawa. Sumatera Utara

Lakitan, B. 1996. Holtikultura: Teori, Budidaya dan Pasca Panen. Rajawali. CV. Yasaguna.

Jakarta. 75 hal.

Lingga, P. 1994. Petujuk Penggunaan Pupuk. Penebar Swadaya. Jakarta

Marsono dan P. Sigit. 200o. Pupuk Akar : Jenis dan Aplikasi. Penebar Swadaya. Jakarta. 2005. Karet. Strategi Pemasaran Budidaya Dan Pengolahan. Penebar Swadaya. Jakarta.
Nazaruddin dan Farry B. Paimin. 1992. Karet, Strategi Pemasaran Tahun 2000 dan Budidaya. Penebar Swadaya. Jakarta.

Nazarudin, dkk.1992.dalam http://ide.wikipedia. Org/wiki/karet [28 April 2008]

Syarif, E.S. 1999. Kesuburan dan Pemupukan Tanah Pertanian. Penerbit Pustaka Buana. Bandung

Setyamidjaja, D. 1993. Karet, Budidaya dan Pengolahan. Kanisius. Yogyakarta. 206

Sutanto, Rachman.2002.Penerapan Pertanian Organik. Yogyakarta: Kanisius

Tim Penulis PS. 2008. Panduan Lengkap Karet. Penebar Swadaya. Jakarta. 235 hal.

Warta Penelitian dan Pengembangan Tanaman Industri. 2012. Prospek dan Pengembangan Agribisnis Karet. Volume 18 Nomor 2, 